\title{
Curcumin suppresses the proliferation of oral squamous cell carcinoma through a specificity protein 1/nuclear factor- $\kappa B$-dependent pathway
}

\author{
TIAN LIU ${ }^{1 *}$, TIAN LONG ${ }^{1 *}$ and HAOSEN LI \\ ${ }^{1}$ Department of Stomatology, The Central Hospital of Wuhan; ${ }^{2}$ Department of Stomatology Center, Tongji Hospital, \\ Tongji Medical College, Huazhong University of Science and Technology, Wuhan, Hubei 430000, P.R. China
}

Received January 21, 2020; Accepted July 17, 2020

DOI: $10.3892 /$ etm.2021.9635

\begin{abstract}
Oral squamous cell carcinoma (OSCC) is the most common cancer of the oral cavity. Curcumin (Cur), a naturally derived compound, is reported to have broad-spectrum anticancer activity and is considered as an effective nuclear factor- $\kappa \mathrm{B}(\mathrm{NF}-\kappa \mathrm{B})$ inhibitor. The present study aimed to clarify the detailed molecular mechanism though which Cur regulates $\mathrm{NF}-\kappa \mathrm{B}$ pathway activity in OSCC. The viability of HSC 3 and CAL33 cells following treatment with Cur was determined using a Cell Counting Kit- 8 assay. The protein and mRNA expression of specificity protein 1 (Sp1), p65 and heat shock factor 1 (HSF1) was determined by western blotting and reverse transcription-quantitative PCR analysis, respectively. The NF- $\kappa$ B activity was measured by Dual-Luciferase reporter assay. Short hairpin RNA targeting Sp1 or control RNA was transfected into HSC3 cells using X-treme GENE HP DNA Transfection System. Colony formation assays were performed using crystal violet staining. The results demonstrated that Cur significantly inhibited the viability and colony formation ability of HSC3 and CAL33 cells. In addition, Cur decreased the expression of Sp1, p65 and HSF1 by suppressing their transcription levels. Cur decreased NF- $\kappa$ B activity in OSCC cells, and Sp1 downregulation enhanced the effect of Cur. The findings from the present study suggested that Cur may inhibit the proliferation of OSCC cells via a Sp1/NF- $\kappa \mathrm{B}$-dependent mechanism.
\end{abstract}

Correspondence to: Dr Haosen Li, Department of Stomatology Center, Tongji Hospital, Tongji Medical College, Huazhong University of Science and Technology, 1095 Jiefang Avenue, Wuhan, Hubei 430000, P.R. China

E-mail: 115926450747@126.com

${ }^{*}$ Contributed equally

Key words: oral squamous cell carcinoma, specificity protein 1, curcumin, nuclear factor- $\kappa \mathrm{B}, \mathrm{p} 65$

\section{Introduction}

Oral squamous cell carcinoma (OSCC) is the most frequent type of head and neck cancer in China (1). The current treatment modalities for OSCC include surgery, which can be functionally debilitating or disfiguring, radiotherapy and chemotherapy. For patients with terminal or advanced cancer, the survival times may be decreased to a few months, which highlights the urgent need for novel therapeutic strategies $(2,3)$.

Curcumin [Cur; 1,7-bis(4-hydroxy-3-methoxyphenyl)-1, 6-heptadiene-3,5-dione] is a natural phenolic compound commonly known as the dietary spice turmeric (Curcuma longa), which is derived from the rhizome of an East Indian plant (4). Cur has been considered as pharmacologically safe for dietary consumption over several centuries (5). Extensive research has revealed that Cur is an effective molecular agent with a broad spectrum of biological activities against aging, inflammation and cancer $(6,7)$. Previous studies have reported that Cur inhibits proliferation, metastasis and initiation of several malignances, including lung, breast, hepatocellular, pancreatic and gastric cancers (8-12). In addition, epidemiological study has suggested that a diet rich in Cur may decrease the incidence of colon cancer (13).

Cur significantly inhibits the activity of the nuclear factor $\kappa \mathrm{B}(\mathrm{NF}-\kappa \mathrm{B})$ pathway in various human carcinomas, such as liver and thyroid carcinoma $(14,15)$. Cur may therefore, be considered as an inhibitor of $\mathrm{NF}-\kappa \mathrm{B}$ by regulating the proteins associated with the $\mathrm{NF}-\kappa \mathrm{B}$ pathway. It was demonstrated that Cur can decrease the expression of p65, which specifically targets cancer stem cell populations and kills liver cancer cells (16). Under hypoxic tumor microenvironment, Cur can effectively inhibit hypoxia-inducible factor $1 \alpha$ (HIF-1 $\alpha)$ and nuclear p65 expression in breast and lung cancer cells, which leads to tumor growth inhibition (10). In addition, Cur can inhibit NF- $\kappa$ B activity in an AKT-dependent manner in head and neck squamous cell carcinoma (17).

Specificity protein 1 (Sp1) is a member of the Sp-family, which is involved in multiple biological processes, including cell apoptosis, differentiation, cell cycle progression and proliferation (18-20). The expression and activation of Sp1 have been reported to be associated with the development of human cancers and prognosis (21). Sp1 is overexpressed 
in several cancers, including pancreatic and gastric cancers, and appears to be associated with poor prognosis, suggesting that $\mathrm{Sp} 1$ could be a potential therapeutic strategy for cancer treatment $(22,23)$. Sp1 is also associated with proliferation, apoptosis and metastasis in oral cancer. Suppression of the tissue inhibitor of metalloproteinase- 3 by promoter methylation of Sp1 contributes to oral cancer metastasis (24). Interfering Sp1 with small interfering (si)RNA or mithramycin A increasingly trigger apoptosis in oral cancer cells (25). A series of Sp1 special target inhibitors were reported to be effective for OSCC treatment, including honokiol, $\beta$-lapachone and esculetin (26-29). In addition, $\mathrm{Sp} 1$ can regulate $\mathrm{NF}-\kappa \mathrm{B}$ pathway activity by increasing the transcriptional level of p65 and p50 in pancreatic cancer and OSCC $(30,31)$.

The present study aimed to investigate the effects and underlying mechanisms of Cur in OSCC. The results indicated that Cur inhibited the proliferation and NF- $\kappa \mathrm{B}$ activity of OSCC cells. Importantly, Cur decreased the expression of Sp1, p65 and HSF1 in OSCC cells. Finally, Sp1 knockdown contributed to the effect of Cur on p65 and HSF1 in OSCC cells, resulting in a decreased NF- $\kappa \mathrm{B}$ activity and cell viability.

\section{Materials and methods}

Cell lines and reagents. HSC3 and CAL33 cell lines were used in the present study. The HSC3 cell line was kindly provided by Dr Xin Zhang (University of Wuhan). The CAL33 cell line was a gift from Dr Juhua Zhou (Hubei University of Medicine). All cells were cultured in DMEM (HyClone; Cytiva) supplemented with 10\% FBS (Gibco; Thermo Fisher Scientific, Inc.) and $1 \%$ antibiotic (penicillin/streptomycin; Sigma-Aldrich; Merck $\mathrm{KGaA}$ ) and placed at $37^{\circ} \mathrm{C}$ in a humidified incubator containing 5\% $\mathrm{CO}_{2}$. Cur (Sigma-Aldrich; Merck KGaA) was dissolved in DMSO (Sigma-Aldrich; Merck KGaA) as a stock solution of $100 \mathrm{mM}$.

Cell viability assay. Previous studies have used 5-20 $\mu \mathrm{M}$ Cur as a work dose in experiments on OSCC and other malignances $(32,33)$. In the present study, HSC3 and CAL33 cells were seeded in 96-well plates $\left(1 \times 10^{4}\right.$ cells/well $)$ and treated with $0.01 \%$ DMSO (control) or increasing concentrations of Cur $(5-20 \mu \mathrm{M})$ at $37^{\circ} \mathrm{C}$. After 24 or $48 \mathrm{~h}$ treatment, cells were incubated with $10 \mu \mathrm{l}$ Cell Counting Kit- 8 reagent (Dojindo Molecular Technologies, Inc.) for $1 \mathrm{~h}$ at $37^{\circ} \mathrm{C}$ in the dark. The optical density was measured using an ELx800 microimmunoanalyser at $450 \mathrm{~nm}$ (BioTek Instruments, Inc.). Data were normalized to the control sample.

Colony formation assay. HSC3 and CAL33 (500 cells) were seeded in $35-\mathrm{mm}$ culture dishes and grown in standard medium with DMSO $(0.01 \%)$ or Cur $(0.5-2 \mu \mathrm{M})$. After 14 days of treatment, cells were incubated with $0.5 \%$ crystal violet-glutaraldehyde solution $(0.6 \%, \mathrm{v} / \mathrm{v})$ for $1 \mathrm{~min}$. After washing with PBS, cell colonies were photographed $(34,35)$.

Western blotting. HSC 3 and CAL33 cells were treated with DMSO $(0.01 \%)$ or Cur $(5,10$ and $20 \mu \mathrm{M})$ for $48 \mathrm{~h}$. Cells were washed, harvested and lysed in RIPA lysis buffer (Beyotime Institute of Biotechnology) containing $0.5 \%$ cocktail protease inhibitor (Roche Diagnostics) on ice for $10 \mathrm{~min}$, collected and sonicated for $15 \mathrm{sec}$. Protein concentration was measured by BCA assay (Bio-Rad Laboratories, Inc.). Proteins were mixed with 5X loading buffer (Chunfeng Lv, China) and boiled for $5 \mathrm{~min}$. Proteins $(20 \mu \mathrm{g})$ were separated by $10 \%$ SDS-PAGE and transferred onto PVDF membranes. After blocking with $5 \%$ skimmed milk in PBS supplemented with $0.01 \%$ Tween-20 for $1 \mathrm{~h}$ at room temperature, membranes were incubated with primary antibodies against $\beta$-actin (cat. no. A-1978; 1:2,000; Sigma-Aldrich; Merck KGaA); Sp1 (cat. no. ab124804; 1:1,000; Abcam); p65 (cat. no. ab16502; 1:1,500; Abcam) and HSF1 (cat. no. 12972; 1:1,000; Cell Signaling Technology, Inc.) overnight at $4^{\circ} \mathrm{C}$. After washing three times with PBS-0.01\% Tween-20, membranes were incubated with HRP-conjugated goat anti-rabbit (cat. no. A9169; 1:2,000) or goat anti-mouse (cat. no. A9309; 1:2,000; both from Sigma-Aldrich; Merck KGaA) secondary antibodies. An ECL kit (cat. no. 1705060; Bio-Rad Laboratories, Inc.) was used to detect the signal. Western blot gray values were determined using ImageJ software (version 1.8.0; National Institutes of Health).

Reverse transcription-quantitative (RT-q)PCR. HSC3 and CAL33 cells ( $1 \times 10^{5}$ cells/well) were seeded in 24 -well plates overnight. Cells were washed with PBS, treated with DMSO $(0.01 \%)$ or Cur $(10$ or $20 \mu \mathrm{M})$ and incubated at $37^{\circ} \mathrm{C}$ for $24 \mathrm{~h}$. Cells were washed with PBS and total RNA was extracted using $0.5 \mathrm{ml}$ TRIzol reagent (Thermo Fisher Scientific, Inc.) according to the manufacturer's instructions. Subsequently, RNA was then reverse transcribed into cDNA using RT kit (Takara Bio, Inc.) according to the manufacturer's instructions. cDNA levels were quantified using the SYBR Premix Ex Taq kit (Takara Bio, Inc.) with the CFX96 Real-Time PCR Detection System. The thermocycling conditions were as follows: Denaturation at $95^{\circ} \mathrm{C}$ for $15 \mathrm{sec}$, annealing at $60^{\circ} \mathrm{C}$ for $15 \mathrm{sec}$ and extension at $72^{\circ} \mathrm{C}$ for $15 \mathrm{sec}$. The replication cycles were repeated 30 times. The sequences of the primers were as follows: p65, forward, 5'-CGGGATGGCTTCTATGA GG-3' and reverse, 5'-CTCCAGGTCCCGCTTCTT-3'; HSF1, forward, 5'-ACCTTCATCGGAAACTCCAAAG-3' and reverse, 5'-CTGTTAGGCTGGGAAAAGTTAGG-3'; Sp1, forward, 5'-GGAGAGCAAAACCAGCAGAC-3' and reverse, 5'-AAGGTGATTGTTTGGGCTTG-3'; and GAPDH, forward, 5'-AGGTCGGTGTGAACGGATTTG-3' and reverse, 5'-TGT AGACCATGTAGTTGAGGTCA-3'. The relative expression levels were normalized to endogenous control and were expressed as $2^{-\Delta \Delta \mathrm{Cq}}(36)$.

Cell transfection. HSC 3 cells were transfected with Sp1-specific short hairpin RNA (shRNA; 5'-GCATATTTGCCACAT CCAAGG-3', Sp1-Homo-1828; GenePharma, Co., Ltd.) or a non-specific control (NC; 5'-TTCTCCGAACGTGTCACG T-3'; Shanghai GenePharma Co., Ltd.) using X-treme GENE HP DNA Transfection Reagent (Roche Diagnostics; 40 pmol for each shRNA) according to the manufacturer's instructions. Furthermore, PCDNA3.1 control vector and pCDNA3.1-Sp1 plasmid were donated by Dr Zilong Gao (Taihe Hospital, Shiyan). HSC3 cells were transfected with pCDNA3.1 and pCDNA3.1-Sp1 $(2 \mu \mathrm{g})$ by using X-treme GENE HP DNA Transfection Reagent. At $4 \mathrm{~h}$ following transfection, Cur or DMSO control was added. Cells were incubated and harvested for the next experiments as follows: Western blotting (48 h), 

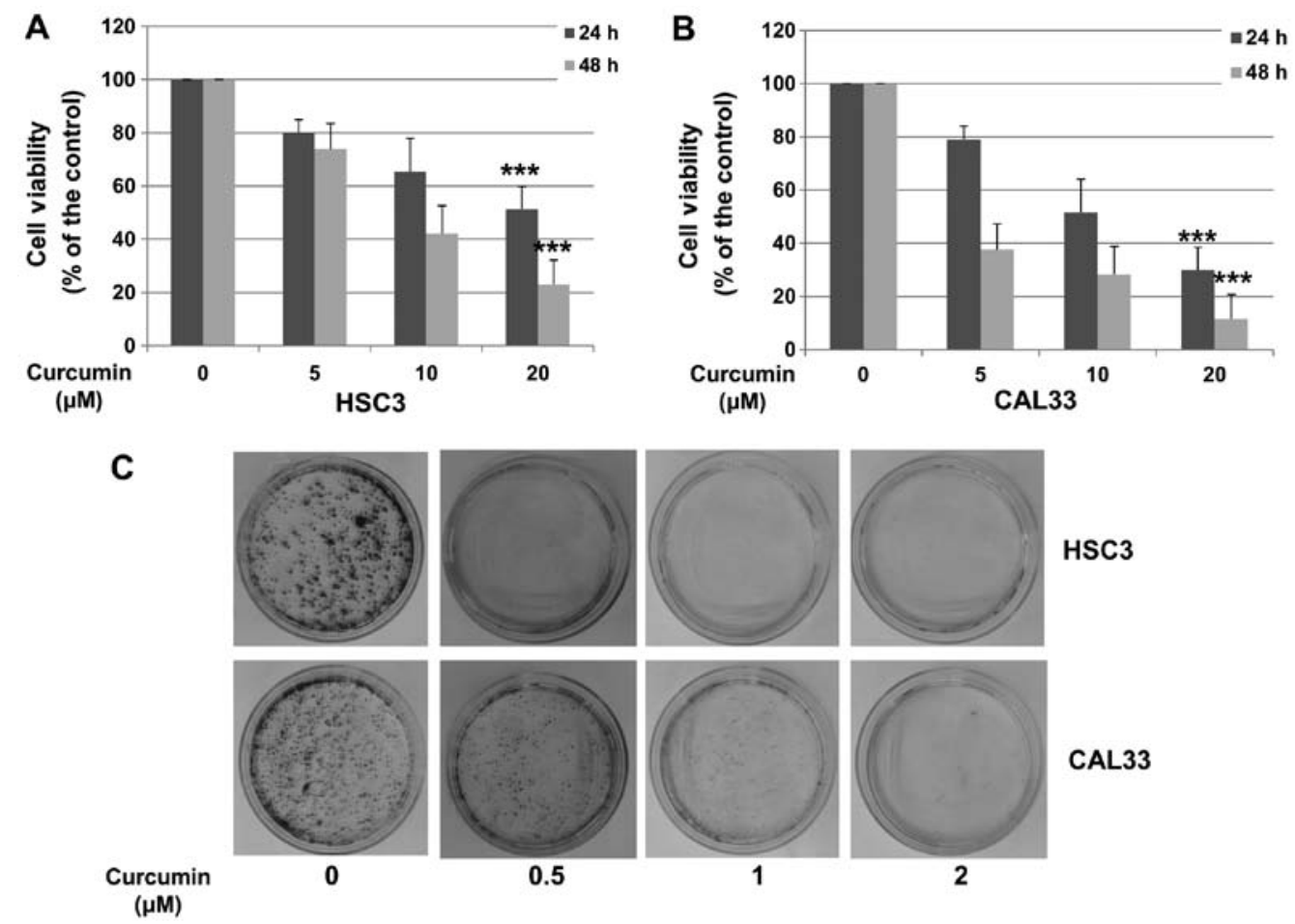

Figure 1. Cur inhibits the proliferation of oral squamous cell carcinoma cells. (A) HSC3 and (B) CAL33 cells were incubated with $0.01 \%$ DMSO (control) or increasing Cur concentrations $(5,10$ and $20 \mu \mathrm{M})$ for 24 and $48 \mathrm{~h}$. Cell viability was determined by using a Cell Counting Kit- 8 assay. Data are presented as the mean \pm standard deviation of three independent experiments performed in triplicate. ${ }^{* * * *} \mathrm{P}<0.001$ vs. control group. (C) HSC3 and CAL33 cells were treated with DMSO $(0.01 \%)$ or Cur $(0.5,1$ and $2 \mu \mathrm{M})$. After 14 days of treatment, cells were stained with $0.5 \%$ crystal violet-glutaraldehyde solution and photographed. Cur, curcumin.

Dual-Luciferase reporter assay (12 h) and Cell Counting Kit-8 assay (24 h).

Dual-Luciferase reporter assay. The NF- $\mathrm{BB}$ activity plasmid and PRL-TK plasmid were kindly provided by Professor $\mathrm{H}$. Shu (University of Wuhan). HSC 3 cells $\left(1 \times 10^{5}\right.$ cells/well) were seeded into 24 -well plates and incubated at $37^{\circ} \mathrm{C}$ overnight. Plasmids were co-transfected using X-treme GENE HP DNA Transfection Reagent into the cells for $24 \mathrm{~h}$. Cells were treated with Cur (10 or $20 \mu \mathrm{M})$ or DMSO $(0.01 \%)$ for 12 or $24 \mathrm{~h}$, then collected and analyzed using the Dual-Luciferase reporter assay system according to the manufacturer's instructions (Promega Corporation). The intensity of NF-kB activity was normalized to the Renilla luciferase activity from the PRL-TK plasmid.

Statistical analysis. Experimental data were presented as the mean \pm standard deviation of three independent experiments. Student's t-test was used for comparing significance between two groups. One-way ANOVA followed by Newman-Keuls or Bonferroni post hoc tests was used to compare data between $>2$ groups. Statistical analysis was performed using SPSS version 12.0 (SPSS, Inc.). P $<0.05$ was considered to indicate a statistically significant difference.

\section{Results}

Cur inhibits OSCC cell proliferation. To determine the effect of Cur on the viability of OSCC cells, HSC 3 and CAL33 cells were treated with various doses of Cur for 24 or $48 \mathrm{~h}$. Cell growth inhibition was compared with DMSO control alone. As presented in Fig. 1A and B, Cur significantly decreased the viability of HSC 3 and CAL33 cells in a concentrationdependent manner $(20 \mu \mathrm{M} ; \mathrm{P}<0.001)$. A colony formation assay was performed to further confirm these results. HSC 3 and CAL33 cells were treated with DMSO or Cur for 14 days and subjected to crystal violet staining. As presented in Fig. 1C, Cur significantly inhibited the colony formation of both HSC3 and CAL33 cells. These results suggested that Cur inhibited the proliferation of HSC3 and CAL33 cell lines.

Cur downregulates Sp1, $p 65$ and HSF1 expression in OSCC cells. The expression of Sp1, p65 and HSF1 following treatment with DMSO (control) or Cur $(5,10$ and $20 \mu \mathrm{M})$ for $48 \mathrm{~h}$ was evaluated in HSC3 and CAL33 cells. Compared with control, Sp1 expression was significantly decreased after Cur treatment in both HSC 3 and CAL33 cells ( $\mathrm{P}<0.001$; Fig. $2 \mathrm{~A}$ and B). It has been reported that $\mathrm{Sp1}$ is a transcription factor of $\mathrm{p} 65$ and HSF1 (31). Subsequently, the expression of p65 and HSF1 was also evaluated. As presented in Fig. 2A and B, Cur treatment significantly decreased the expression of p65 $(\mathrm{P}<0.001)$ and HSF1 $(\mathrm{P}<0.001)$ in OSCC cells compared with the control.

Cur decreases the expression level of Sp1, p65 and HSF1 in OSCC cells. In order to determine whether the decreased protein expression in OSCC cells was associated with decreased mRNA levels, RT-qPCR was performed. HSC3 and CAL33 cells were incubated with or without Cur for 12 or $24 \mathrm{~h}$. As presented in Fig. 3A and D, the mRNA expression of Sp1 in $\mathrm{HSC} 3$ [12 $\mathrm{h}(\mathrm{P}=0.0036)$ and $24 \mathrm{~h}(\mathrm{P}<0.001)]$ and CAL33 

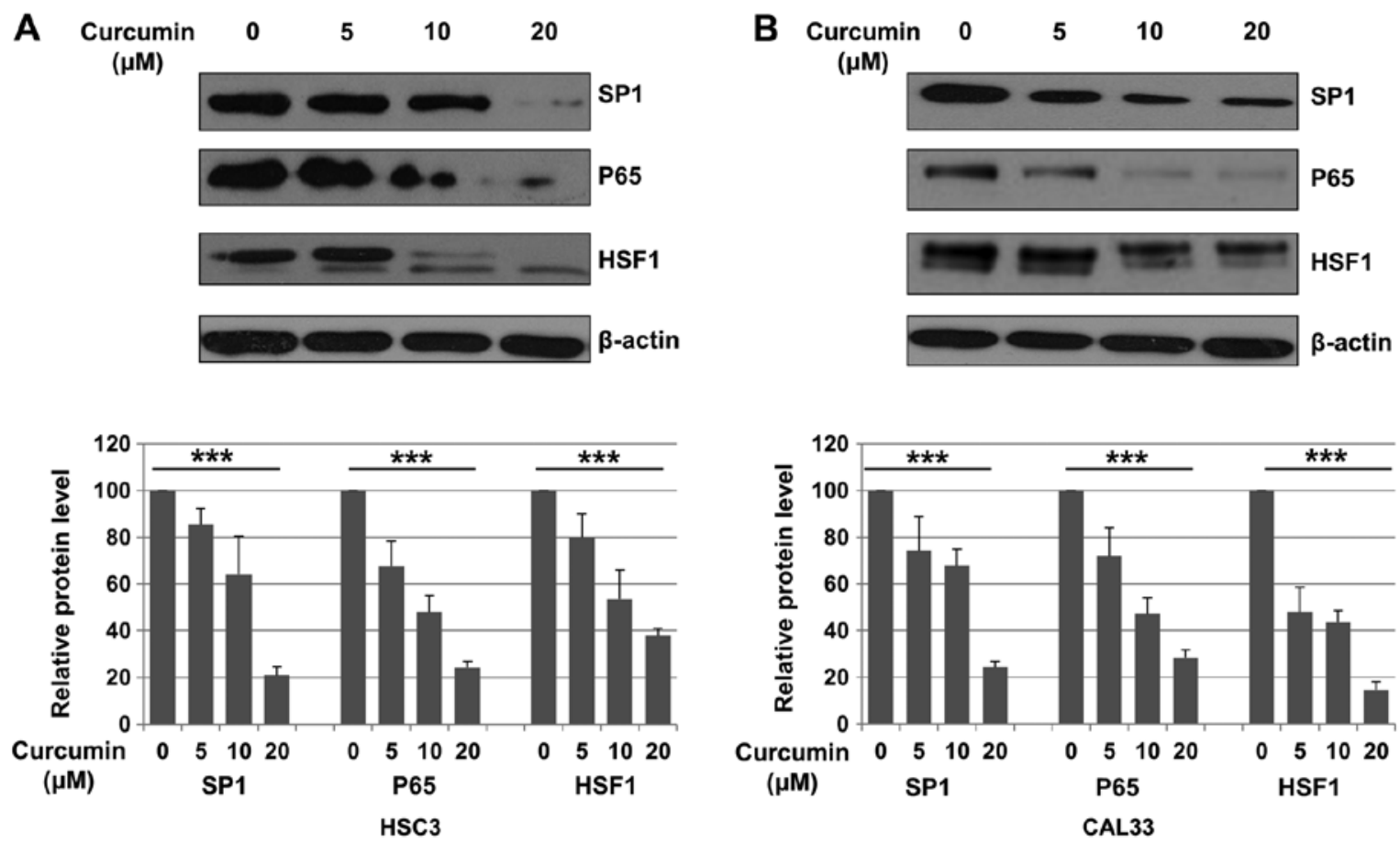

Figure 2. Cur inhibits the expression of Sp1, p65 and HSF1 in oral squamous cell carcinoma cell lines. (A) HSC3 and (B) CAL33 cells were treated with either $0.01 \%$ DMSO or Cur $(5,10$ and $20 \mu \mathrm{M})$ for $48 \mathrm{~h}$ and then subjected to western blotting. Expression of Sp1, p65 and HSF-1 was measured. Data are presented as the mean \pm standard deviation of three independent experiments performed in triplicate. ${ }^{* * *} \mathrm{P}<0.001$ vs. control group. Cur, curcumin; Sp1, specificity protein 1; HSF1, heat shock factor 1 .

$[12 \mathrm{~h}(\mathrm{P}<0.001)$ and $24 \mathrm{~h}(\mathrm{P}<0.001)]$ cells was decreased following treatment with $20 \mu \mathrm{M}$ Cur. Furthermore, Cur treatment significantly downregulated the expression levels of p65 [Fig. 3B (12 h, P=0.0052; 24 h, P<0.001) and Fig. 3E (12 h, $\mathrm{P}=0.0083 ; 24 \mathrm{~h}, \mathrm{P}=0.0021)$ ] and HSF1 [Fig. 3C (12 h, $\mathrm{P}<0.001$; $24 \mathrm{~h}, \mathrm{P}<0.001)$ and Fig. 3E (12 h, $\mathrm{P}<0.001 ; 24$ h, $\mathrm{P}<0.001)]$ in both OSCC cell lines. These results suggested that Cur decreased the expression of Sp1, p65 and HSF1 in OSCC cells by downregulating their transcriptional levels.

Cur decreases $N F-\kappa B$ activity in OSCC cells. Downregulation of p65 was reported to decrease the activity of the NF- $\kappa \mathrm{B}$ pathway (31). To determine whether Cur could inhibit NF- $\kappa \mathrm{B}$ activity in OSCC cells, HSC3 and CAL33 cells were incubated with DMSO (control) or Cur, and the activity of the $\mathrm{NF}-\kappa \mathrm{B}$ pathway was determined via Dual-Luciferase reporter assay. As presented in Fig. 4A and B, after $24 \mathrm{~h}$ treatment, $20 \mu \mathrm{M}$ Cur significantly decreased the activity of NF- $\kappa \mathrm{B}$ by 88.2 and $95.4 \%$ in HSC3 and CAL33 cell lines, respectively.

Cur inhibits cell proliferation and $N F-\kappa B$ activity in a Spl-dependent manner. To determine whether the effects of Cur on cell viability and $\mathrm{NF}-\kappa \mathrm{B}$ pathway are dependent of Sp1, HSC3 cells were transfected with control shRNA or shRNA-Sp1, and treated with Cur or DMSO (control). As presented in Fig. 5A, shRNA-Sp1 significantly downregulated the expression of Sp1, p65 and HSF1, and enhanced the inhibitory effect of Cur on the expression of these proteins. In addition, Sp1 knockdown significantly enhanced the effect of

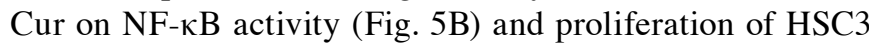
cells (Fig. 5C). To further confirm these results, pcDNA3.1 or pcDNA3.1-Sp1 was transfected into HSC3 cells, which were subsequently treated with Cur or DMSO (control). As presented in Fig. 5D, pcDNA3.1 significantly upregulated Sp1, p65 and HSF1 expression, and attenuated the effect of Cur on the expression of these proteins. In addition, overexpression of Sp1 significantly reversed the effect of Cur on NF- $\kappa B$ activity (Fig. 5E) and proliferation of HSC3 cells (Fig. 5F). These results suggested that Cur may inhibit OSCC cell proliferation and $N F-\kappa B$ activity via $S p 1$ regulation.

\section{Discussion}

Chemotherapy is a treatment of choice for OSCC. Most anticancer drugs ( $\sim 80 \%)$ are derived from natural products or analogues based on natural products, such as triptolide and baicalein (37). Numerous studies have reported the potent antitumor activities of Cur in various types of cancer in vivo and in vitro, including pancreatic, lung, breast, colorectal, ovarian, gastric and head and neck cancers (17,38-42). In phase I clinical trials, Cur is not associated with significant side effects in animals or patients with breast, bladder or pancreatic cancers (43-45). In the present study, Cur significantly inhibited the proliferation of OSCC cells, and significantly decreased the protein and mRNA levels of Sp1, p65 and HSF1. In addition, Cur inhibited NF- $\mathrm{B}$ activity in OSCC cells. Furthermore, the downregulation of Sp1 significantly decreased the expression of p65 and HSF1 and enhanced the inhibitory effect of Cur on cell proliferation and $\mathrm{NF}-\kappa \mathrm{B}$ activity.

$\mathrm{NF}-\kappa \mathrm{B}$ highly contributes to tumor cell survival, proliferation and metastasis and exerts anti-apoptotic effects on various types of cancer, including OSCC (46). Tumor necrosis factor- $\alpha$ is known to enhance the invasive and metastatic abilities of OSCC cells by increasing the 
A

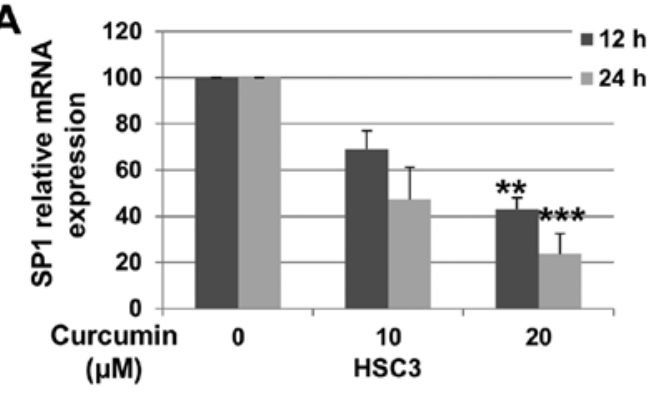

B
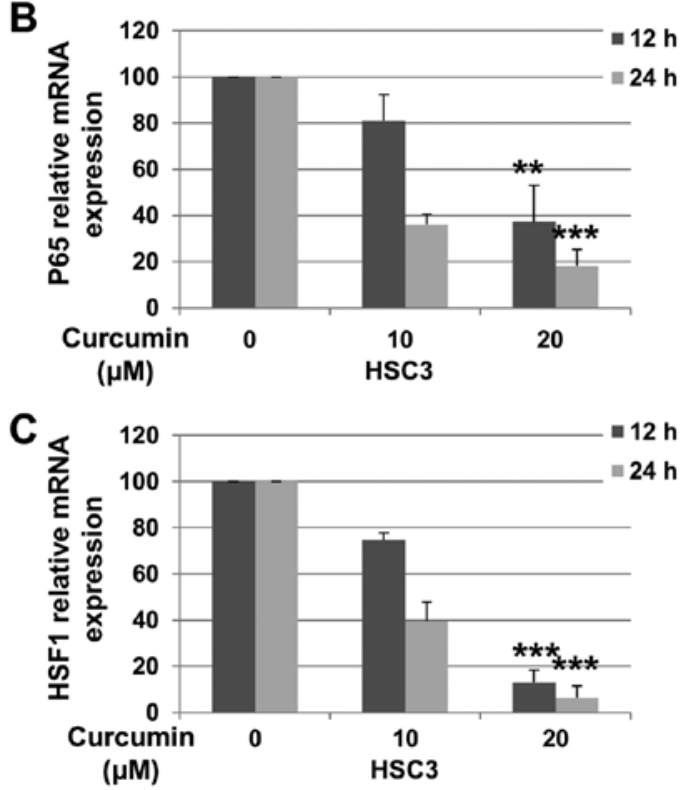

D

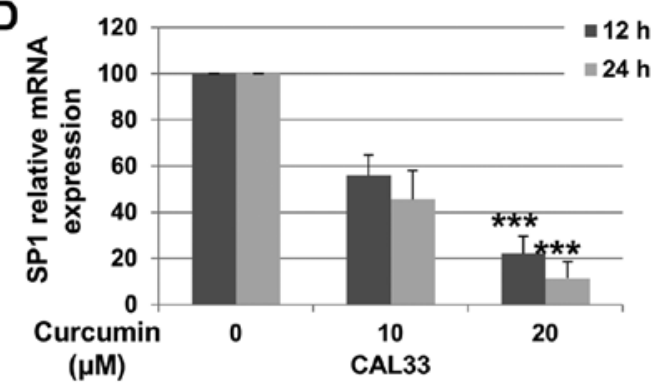

E

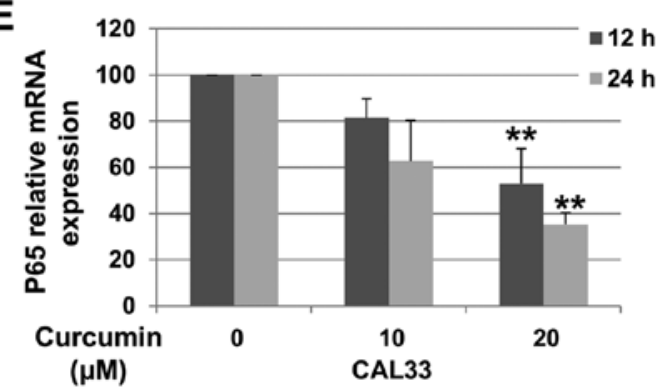

$\mathbf{F}$

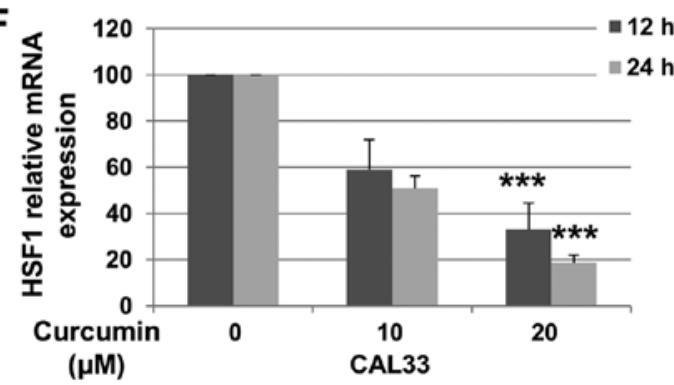

Figure 3. Cur inhibits the transcription levels of Sp1, p65 and HSF1 in oral squamous cell carcinoma cell lines. HSC3 and CAL33 cells were exposed to either $0.01 \%$ DMSO or Cur $(10$ and $20 \mu \mathrm{M})$ for 12 or $24 \mathrm{~h}$ and then subjected to reverse transcription-quantitative PCR analysis. mRNA levels of (A and D) Sp1, (B and E) p65 and (C and F) HSF1 were examined. Data are presented as the mean \pm standard deviation of three independent experiments performed in triplicate. ${ }^{* *} \mathrm{P}<0.01$ and ${ }^{* * *} \mathrm{P}<0.001$ vs. control group. Cur, curcumin; Sp1, specificity protein 1; HSF1, heat shock factor 1.


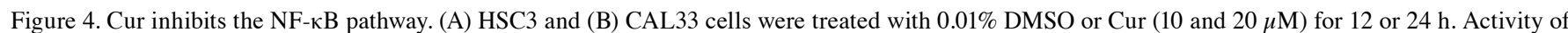
$\mathrm{NF}-\mathrm{\kappa B}$ was measured by the Dual-Luciferase reporter assay system. Data are presented as the mean \pm standard deviation of three independent experiments performed in triplicate. ${ }^{* * *} \mathrm{P}<0.001$ vs. control group. Cur, curcumin; $\mathrm{NF}-\mathrm{kB}$, nuclear factor- $\mathrm{\kappa B}$.

expression of $\mathrm{p} 65$ and IKK $\beta$ (47). NF- $\mathrm{\kappa B}$ has been reported to increase the expression of matrix metalloprotease-9, which is associated with distant lymph node metastasis and poor survival of patients with OSCC (48). It has been demonstrated that upregulated expression of activator protein 1 (AP-1) and NF- $\mathrm{kB}$ in OSCC tissues is involved in $\mathrm{Bcl}-2$ gene regulation, which promotes cancer progression and resistance to chemoradiotherapy (49). In previous clinical studies, NF- $\kappa \mathrm{B}$ overexpression has been associated with negative prognosis of patients with OSCC, pancreatic cancer and laryngeal squamous cell carcinoma (50-52). p65 may therefore serve a critical role in the development and progression of OSCC and may be considered as a potent therapeutic target. 

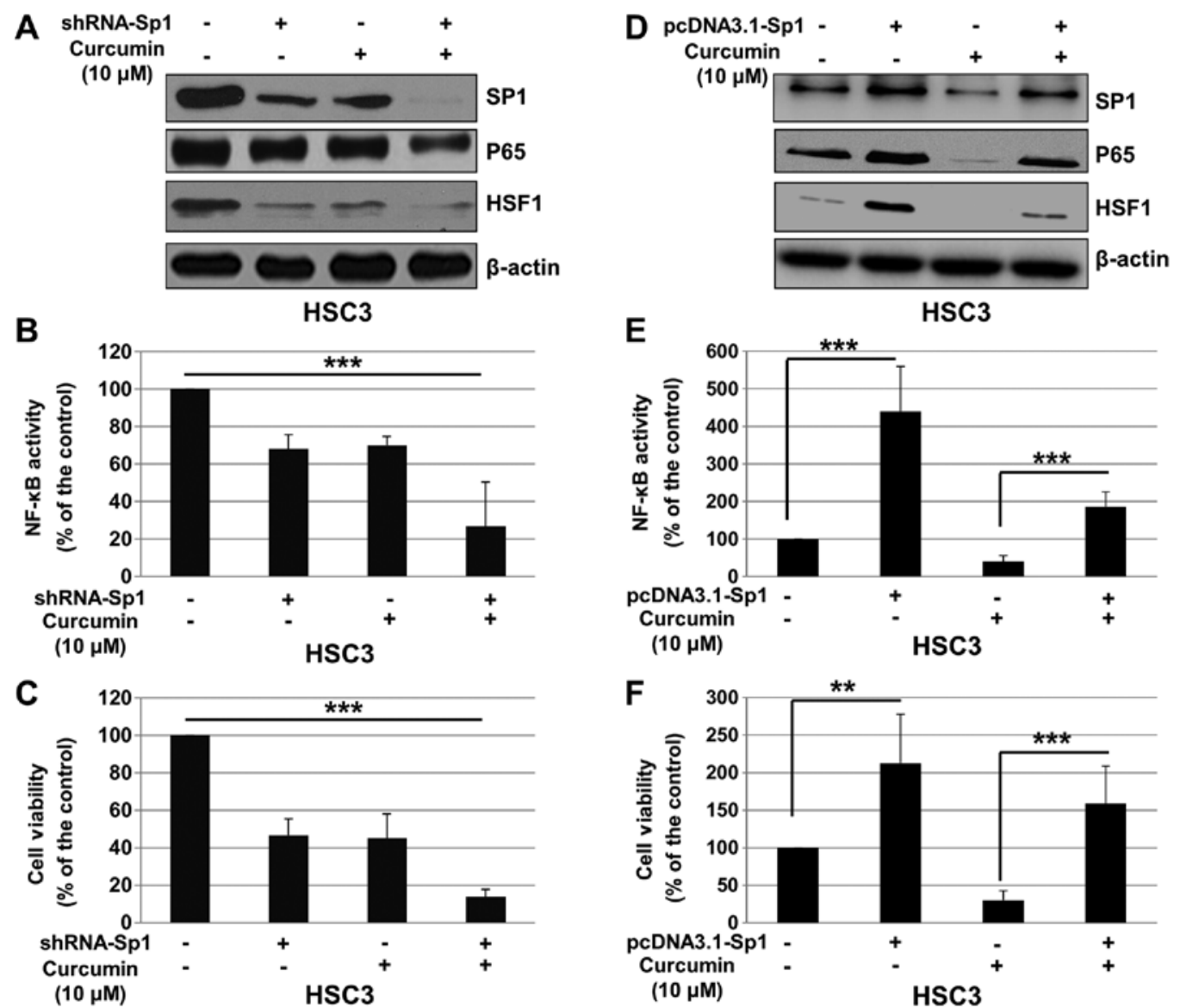

Figure 5. Cur inhibits cell proliferation and NF- $\mathrm{kB}$ activity of oral squamous cell carcinoma cells in a Sp1-dependent manner. HSC 3 cells were transfected with control RNA or shRNA-Sp1 for $4 \mathrm{~h}$, followed by treatment with Cur $(10 \mu \mathrm{M})$ for $48 \mathrm{~h}$. (A) Expression of Sp1, p65 and HSF1 was detected by western blotting after $48 \mathrm{~h}$ treatment. (B) NF- $\mathrm{kB}$ activity was determined using a Dual-Luciferase reporter assay system at $12 \mathrm{~h}$. (C) Cell viability was determined by a Cell Counting Kit-8 assay after $24 \mathrm{~h}$ treatment. HSC3 cells were transfected with pcDNA3.1 or pcDNA3.1-Sp1 for $4 \mathrm{~h}$, followed by treatment with Cur (10 $\mu \mathrm{M})$ for $48 \mathrm{~h}$. (D) Expression of Sp1, p65 and HSF1 was detected by western blotting after $48 \mathrm{~h}$ treatment. (E) NF- $\mathrm{kB}$ activity was determined using a Dual-Luciferase reporter assay system at $12 \mathrm{~h}$. (F) Cell viability was determined by a Cell Counting Kit- 8 assay after $24 \mathrm{~h}$ treatment. Data are presented as the mean \pm standard deviation of three independent experiments performed in triplicate. ${ }^{* *} \mathrm{P}<0.01$ and ${ }^{* * * *} \mathrm{P}<0.001$ vs. control group. Cur, curcumin; NF- $\mathrm{\kappa B}$, nuclear factor- $\kappa \mathrm{B}$; Sp1, specificity protein 1 ; HSF1, heat shock factor 1 ; shRNA, short hairpin RNA.

Cur is commonly known as a special inhibitor targeting p65 and suppressing NF- $\kappa$ B activity in multiple human cancer cells, including lung, breast and liver cancer cells $(10,14)$. In addition to targeting p65, Cur has been reported to sensitize cancer cells to radiation by decreasing the expression of inhibitor of NF- $\kappa \mathrm{B} \alpha(\mathrm{I} \kappa \mathrm{B} \alpha)$ and inhibiting NF- $\mathrm{kB}$ activity (53). Furthermore, Cur can promote paclitaxel-induced apoptosis of human papillomavirus-positive cervical cancer cells via the NF- $\kappa B-p 53-c a s p a s e-3$ pathway (54). Previous studies have demonstrated that Cur inhibits OSCC growth by inhibiting $\mathrm{NF}-\kappa \mathrm{B}$ pathway through various mechanisms $(32,33,55)$. By inhibiting NF- $\kappa \mathrm{B}$ activity, Cur has been indicated to enhance OSCC radiosensitivity in vivo and in vitro (32). Cur treatment has been revealed to inhibit the release of epithelial-to-mesenchymal transition (EMT) mediators in carcinoma-associated fibroblasts and induce the reversal of EMT in tumor cells, which was indicated to decrease the invasion efficiency of OSCC cells (33). To the best of our knowledge, the present study was the first to demonstrate that Cur could downregulate p65, which may account for the decreased NF-KB activity and viability of OSCC cells.

It has been reported that $\mathrm{Sp} 1$ is overexpressed in OSCC tissues compared with adjacent normal oral mucosal tissues, suggesting that Sp1 may be considered as a potential target for treating OSCC (56). Numerous drugs targeting Sp1, including mithramycin A, have exhibited strong inhibitory effects against OSCC cell proliferation (56-58). It was previously reported that baicalein decreases the expression of the NF- $\kappa \mathrm{B}$ subunits $\mathrm{p} 50$ and $\mathrm{p} 65$, in a Sp1-dependent manner in OSCC cells, indicating that baicalein may inhibit NF-кB pathway and OSCC cell proliferation (30). Since Cur has been reported to decrease Sp1 expression in various cancer cells, including osteosarcoma and non-small cell lung cancer cells $(59,60)$, the expression of Sp1 was detected in OSCC cells following Cur treatment. The results demonstrated that $\mathrm{Sp} 1$ expression was significantly decreased in OSCC cells following Cur treatment. In addition, Sp1 silencing significantly downregulated the expression levels of p65 and HSF1, which were detected to evaluate the effect of Cur on Sp1 expression. Furthermore, shRNA-Sp1 significantly contributed to the effect of Cur on cell viability and NF- $\mathrm{KB}$ pathway activity, which suggested that Cur may inhibit OSCC cell proliferation in a Sp1-dependent manner. One limitation of the present study was that transfection experiments were only performed on HSC3 cell line.

In conclusion, the present study demonstrated that Cur inhibited the proliferation and NF- $\mathrm{kB}$ activity of OSCC cells. 
In addition, Cur was shown to decrease the expression of Sp1, p65 and HSF1 in OSCC cells. Sp1 knockdown contributed to the effect of Cur on p65 and HSF1 in OSCC cells, resulting in the decreased activity of $\mathrm{NF}-\kappa \mathrm{B}$ and cell viability. These findings suggested that Cur may inhibit OSCC cell proliferation throuh a $\mathrm{Sp} 1 / \mathrm{NF}-\kappa \mathrm{B}-$ dependent pathway.

\section{Acknowledgements}

The authors would like to thank Dr Xiao Zhang (University of Wuhan, China), Dr Jie Zhou (Hubei University of Medicine, Shiyan, China), Dr Zilong Gao (Taihe Hospital, Shiyan) and Dr Hongbin Shu (University of Wuhan, Wuhan) for supplying the cell lines and plasmids.

\section{Funding}

The present study was supported by the Nature Science Foundation of Hubei province for Young Scholars (grant no. H3561204), without commercial or not-for-profit sectors.

\section{Availability of data and materials}

The datasets used and/or analyzed during the current study are available from the corresponding author on reasonable request.

\section{Authors' contributions}

HL designed the study. TLo performed the experiments. TLi prepared the new reagents/analytic tools. TLo analyzed the data. TLo and TLi wrote the manuscript. All authors read and approved the final manuscript.

\section{Ethics approval and consent to participate}

Not applicable.

\section{Patient consent for publication}

Not applicable.

\section{Competing interests}

The authors declare that they have no competing interests.

\section{References}

1. Gansler T, Ganz PA, Grant M, Greene FL, Johnstone P, Mahoney M, Newman LA, Oh WK, Thomas CR Jr, Thun MJ, et al Sixty years of CA: A cancer journal for clinicians. CA Cancer J Clin 60: 345-350, 2010.

2. Sinevici N and O'Sullivan J: Oral cancer: Deregulated molecular events and their use as biomarkers. Oral Oncol 61: 12-18, 2016.

3. Forastiere A, Koch W, Trotti A and Sidransky D: Head and neck cancer. N Engl J Med 345: 1890-1900, 2001.

4. Hatcher H, Planalp R, Cho J, Torti FM and Torti SV: Curcumin: From ancient medicine to current clinical trials. Cell Mol Life Sci 65: 1631-1652, 2008.

5. Ammon HP and Wahl MA: Pharmacology of curcuma longa. Planta Med 57: 1-7, 1991.

6. Aggarwal BB: Targeting inflammation-induced obesity and metabolic diseases by curcumin and other nutraceuticals. Annu Rev Nutr 30: 173-199, 2010.
7. Sri Ramya PV, Guntuku L, Angapelly S, Karri S, Digwal CS Babu BN, Naidu VGM and Kamal A: Curcumin inspired 2-chloro/phenoxy quinoline analogues: Synthesis and biological evaluation as potential anticancer agents. Bioorg Med Chem Lett 28: 892-898, 2018.

8. Lelli D, Pedone C, Majeed M and Sahebkar A: Curcumin and lung cancer: The role of microRNAs. Curr Pharm Des 23: 3440-3444, 2017.

9. Basha R, Connelly SF, Sankpal UT, Nagaraju GP, Patel H, Vishwanatha JK, Shelake S, Tabor-Simecka L, Shoji M, Simecka JW and El-Rayes B: Small molecule tolfenamic acid and dietary spice curcumin treatment enhances antiproliferative effect in pancreatic cancer cells via suppressing Sp1, disrupting NF-kB translocation to nucleus and cell cycle phase distribution. J Nutr Biochem 31: 77-87, 2016.

10. Chatterjee B, Ghosh K, Suresh L and Kanade SR: Curcumin ameliorates PRMT5-MEP50 arginine methyltransferase expression by decreasing the Sp1 and NF-YA transcription factors in the A549 and MCF-7 cells. Mol Cell Biochem 455: 73-90, 2019.

11. Hassanalilou T, Ghavamzadeh S and Khalili L: Curcumin and gastric cancer: A review on mechanisms of action. J Gastrointest Cancer 50: 185-192, 2019.

12. Zhang HH, Zhang Y, Cheng YN, Gong FL, Cao ZQ, Yu LG and Guo XL: Metformin incombination with curcumin inhibits the growth, metastasis, and angiogenesis of hepatocellular carcinoma in vitro and in vivo. Mol Carcinog 57: 44-56, 2018.

13. Mohandas KM and Desai DC: Epidemiology of digestive tract cancers in India. V. Large and small bowel. Indian J Gastroenterol 18: 118-121, 1999.

14. Marquardt JU, Gomez-Quiroz L, Arreguin Camacho LO, Pinna F, Lee YH, Kitade M, Domínguez MP, Castven D, Breuhahn K, Conner EA, et al: Curcumin effectively inhibits oncogenic NF- $\mathrm{NB}$ signaling and restrains stemness features in liver cancer. J Hepatol 63: 661-669, 2015.

15. Schwertheim S, Wein F, Lennartz K, Worm K, Schmid KW and Sheu-Grabellus SY: Curcumin induces G2/M arrest, apoptosis, $\mathrm{NF}-\kappa \mathrm{B}$ inhibition, and expression of differentiation genes in thyroid carcinoma cells. J Cancer Res Clin Oncol 143: 1143-1154, 2017.

16. Huang Y, Hu L, Huang S, Xu W, Wan J, Wang D, Zheng G and Xia Z: Curcumin-loaded galactosylated BSA nanoparticles as targeted drug delivery carriers inhibit hepatocellular carcinoma cell proliferation and migration. Int $\mathbf{J}$ Nanomedicine 13: 8309-8323, 2018.

17. Wang D, Veena MS, Stevenson K, Tang C, Ho B, Suh JD, Duarte VM, Faull KF, Mehta K, Srivatsan ES and Wang MB: Liposome-encapsulated curcumin suppresses growth of head and neck squamous cell carcinoma in vitro and in xenografts through the inhibition of nuclear factor kappaB by an AKT-independent pathway. Clin Cancer Res 14: 6228-6236, 2008.

18. Shi Q, Le X, Abbruzzese JL, Peng Z, Qian CN, Tang H, Xiong Q, Wang B, Li XC and Xie K: Constitutive Spl activity is essential for differential constitutive expression of vascular endothelial growth factor in human pancreatic adenocarcinoma. Cancer Res 61: 4143-4154, 2001.

19. Abdelrahim M, Smith R III, Burghardt R and Safe S: Role of Sp proteins in regulation of vascular endothelial growth factor expression and proliferation of pancreatic cancer cells. Cancer Res 64: 6740-6749, 2004.

20. Black AR, Black JD and Azizkhan-Clifford J: Sp1 and kruppel-like factor family of transcription factors in cell growth regulation and cancer. J Cell Physiol 188: 143-160, 2001.

21. Safe $\mathrm{S}$ and Abdelrahim M: Sp transcription factor family and its role in cancer. Eur J Cancer 41: 2438-2448, 2005.

22. Hu H, Wu LL, Han T, Zhuo M, Lei W, Cui JJ, Jiao F and Wang LW: Correlated high expression of FXR and Sp1 in cancer cells confers a poor prognosis for pancreatic cancer: A study based on TCGA and tissue microarray. Oncotarget 8: 33265-33275, 2017.

23. Jiang W, Jin Z, Zhou F, Cui J, Wang L and Wang L: High co-expression of Sp1 and HER-2 is correlated with poor prognosis of gastric cancer patients. Surg Oncol 24: 220-225, 2015.

24. Su CW, Chang YC, Chien MH, Hsieh YH, Chen MK, Lin CW and Yang SF: Loss of TIMP3 by promoter methylation of Sp1 binding site promotes oral cancer metastasis. Cell Death Dis 10: 793, 2019.

25. Yu HJ, Shin JA, Nam JS, Kang BS and Cho SD: Apoptotic effect of dibenzylideneacetone on oral cancer cells via modulation of specificity protein 1 and Bax. Oral Dis 19: 767-774, 2013. 
26. Cho JH, Shin JC, Cho JJ, Choi YH, Shim JH and Chae JI: Esculetin (6,7-dihydroxycoumarin): A potential cancer chemopreventive agent through suppression of $\mathrm{Spl}$ in oral squamous cancer cells. Int J Oncol 46: 265-271, 2015.

27. Jeon YJ, Bang W, Choi YH, Shim JH and Chae JI: Beta-lapachone suppresses non-small cell lung cancer proliferation through the regulation of specificity protein 1. Biol Pharm Bull 38: 1302-1308, 2015.

28. Jeon YJ, Bang W, Shin JC, Park SM, Cho JJ, Choi YH, Seo KS, Choi NJ, Shim JH and Chae JI: Downregulation of Sp1 is involved in $\beta$-lapachone-induced cell cycle arrest and apoptosis in oral squamous cell carcinoma. Int J Oncol 46: 2606-2612, 2015.

29. Kim DW, Ko SM, Jeon YJ, Noh YW, Choi NJ, Cho SD, Moon HS, Cho YS, Shin JC, Park SM, et al: Anti-proliferative effect of honokiol in oral squamous cancer through the regulation of specificity protein 1. Int J Oncol 43: 1103-1110, 2013.

30. Gao Z, Zhang Y, Zhou H and Lv J: Baicalein inhibits the growth of oral squamous cell carcinoma cells by downregulating the expression of transcription factor Sp1. Int J Oncol 56: 273-282, 2020.

31. Banerjee S, Sangwan V, McGinn O, Chugh R, Dudeja V, Vickers SM and Saluja AK: Triptolide-induced cell death in pancreatic cancer is mediated by O-GlcNAc modification of transcription factor Sp1. J Biol Chem 288: 33927-33938, 2013.

32. Chiang IT, Liu YC, Hsu FT, Chien YC, Kao CH, Lin WJ, Chung JG and Hwang JJ: Curcumin synergistically enhances the radiosensitivity of human oral squamous cell carcinoma via suppression of radiation-induced NF- $\mathrm{kB}$ activity. Oncol Rep 31: 1729-1737, 2014

33. Dudás J, Fullar A, Romani A, Pritz C, Kovalszky I, Hans Schartinger V, Mathias Sprinzl G and Riechelmann H: Curcumin targets fibroblast-tumor cell interactions in oral squamous cell carcinoma. Exp Cell Res 319: 800-809, 2013.

34. Jiang L and Xiao J: 2-phenylethynesulfonamide inhibits growth of oral squamous cell carcinoma cells by blocking the function of heat shock protein 70. Biosci Reps 40, BSR20200079, 2020.

35. Zhang Y, Wang H, Liu Y, Wang C, Wang J, Long C, Guo W and Sun X: Baicalein inhibits growth of Epstein-Barr virus-positive nasopharyngeal carcinoma by repressing the activity of EBNA1 Q-promoter. Biomed Pharmacothe 102: 1003-1014, 2018.

36. Livak KJ and Schmittgen TD: Analysis of relative gene expression data using real-time quantitative PCR and the 2(-Delta Delta C(T)) method. Methods 25: 402-408, 2001.

37. Newman DJ, Cragg GM and Snader KM: Natural products as sources of new drugs over the period 1981-2002. J Nat Prod 66: $1022-1037,2003$

38. Zhang Q, Qiao H, Wu D, Lu H, Liu L, Sang X, Li D and Zhou Y: Curcumin potentiates the galbanic acid-induced anti-tumor effect in non-small cell lung cancer cells through inhibiting Akt/mTOR signaling pathway. Life Sci 239: 117044, 2019.

39. Li W, Wang Z, Xiao X, Han L, Wu Z, Ma Q and Cao L: Curcumin attenuates hyperglycemia-driven EGF-induced invasive and migratory abilities of pancreatic cancer via suppression of the ERK and AKT pathways. Oncol Rep 41: 650-658, 2019.

40. Pereira MC, Mohammed R, Van Otterlo WAL, De Koning CB and Davids H: In vitro analysis of the combinatory effects of novel aminonaphthoquinone derivatives and curcumin on breast cancer progression. Anticancer Res 40: 229-238, 2020.

41. Tian M, Tian D, Qiao X, Li J and Zhang L: Modulation of Myb-induced NF-kB-STAT3 signaling and resulting cisplatin resistance in ovarian cancer by dietary factors. J Cell Physiol 234: 21126-21134, 2019.

42. Boven L, Holmes SP, Latimer B, McMartin K, Ma X, Moore-Medlin T, Khandelwal AR, McLarty J and Nathan CO: Curcumin gum formulation for prevention of oral cavity head and neck squamous cell carcinoma. Laryngoscope 129: 1597-1603, 2019.

43. Cheng AL, Hsu CH, Lin JK, Hsu MM, Ho YF, Shen TS, Ko JY, Lin JT, Lin BR, Ming-Shiang W, et al: Phase I clinical trial of curcumin, a chemopreventive agent, in patients with high-risk or pre-malignant lesions. Anticancer Res 21: 2895-2900, 2001.

44. Kanai M, Yoshimura K, Asada M, Imaizumi A, Suzuki C, Matsumoto S, Nishimura T, Mori Y, Masui T, Kawaguchi Y, et al: A phase I/II study of gemcitabine-based chemotherapy plus curcumin for patients with gemcitabine-resistant pancreatic cancer. Cancer Chemother Pharmacol 68: 157-164, 2011.
45. Bayet-Robert M, Kwiatkowski F, Leheurteur M, Gachon F, Planchat E, Abrial C, Mouret-Reynier MA, Durando X, Barthomeuf $\mathrm{C}$ and Chollet P: Phase I dose escalation trial of docetaxel plus curcumin in patients with advanced and metastatic breast cancer. Cancer Biol Ther 9: 8-14, 2010.

46. Monisha J, Roy NK, Bordoloi D, Kumar A, Golla R, Kotoky J, Padmavathi G and Kunnumakkara AB: Nuclear factor Kappa B: A potential target to persecute head and neck cancer. Curr Drug Targets 18: 232-253, 2017.

47. Tang D, Tao D, Fang Y, Deng C, Xu Q and Zhou J: TNF-alpha promotes invasion and metastasis via NF-Kappa B pathway in oral squamous cell carcinoma. Med Sci Monit Basic Res 23: 141-149, 2017.

48. Bond M, Fabunmi RP, Baker AH and Newby AC: Synergistic upregulation of metalloproteinase- 9 by growth factors and inflammatory cytokines: An absolute requirement for transcription factor NF-kappa B. FEBS Lett 435: 29-34, 1998.

49. Alam M, Kashyap T, Pramanik KK, Singh AK, Nagini S and Mishra R: The elevated activation of $\mathrm{NF} \kappa \mathrm{B}$ and AP-1 is correlated with differential regulation of $\mathrm{Bcl}-2$ and associated with oral squamous cell carcinoma progression and resistance. Clin Oral Investig 21: 2721-2731, 2017.

50. Yoshida K, Sasaki R, Nishimura H, Okamoto Y, Suzuki Y, Kawabe T, Saito M, Otsuki N, Hayashi Y, Soejima T, et al: Nuclear factor-kappaB expression as a novel marker of radioresistance in Early-stage laryngeal cancer. Head Neck 32: 646-655, 2010.

51. Yang SH, Hsu CH, Lee JC, Tien YW, Kuo SH and Cheng AL: Nuclear expression of glioma-associated oncogene homolog 1 and nuclear factor $-\kappa \mathrm{B}$ is associated with a poor prognosis of pancreatic cancer. Oncology 85: 86-94, 2013.

52. Jiang LZ, Wang P, Deng B, Huang C, Tang WX, Lu HY and Chen HY: Overexpression of forkhead box M1 transcription factor and nuclear factor- $\kappa \mathrm{B}$ in laryngeal squamous cell carcinoma: $\mathrm{A}$ potential indicator for poor prognosis. Hum Pathol 42: 1185-1193, 2011.

53. Qiao Q, Jiang Y and Li G: Curcumin improves the antitumor effect of X-ray irradiation by blocking the NF- $\kappa$ B pathway: An in-vitro study of lymphoma. Anticancer Drugs 23: 597-605, 2012.

54. Teymouri M, Pirro M, Johnston TP and Sahebkar A: Curcumin as a multifaceted compound against human papilloma virus infection and cervical cancers: A review of chemistry, cellular, molecular, and preclinical features. Biofactors 43: 331-346, 2017.

55. Shin HK, Kim J, Lee EJ and Kim SH: Inhibitory effect of curcumin on motility of human oral squamous carcinoma YD-10B cells via suppression of ERK and NF-kappaB activations. Phytother Res 24: 577-582, 2010.

56. Shin JA, Kim JJ, Choi ES, Shim JH, Ryu MH, Kwon KH, Park HM, Seo JY, Lee SY, Lim DW, et al: In vitro apoptotic effects of methanol extracts of dianthus chinensis and Acalypha australis L. targeting specificity protein 1 in human oral cancer cells. Head Neck 35: 992-998, 2013.

57. Sachita K, Yu HJ, Yun JW, Lee JS and Cho SD: YM155 induces apoptosis through downregulation of specificity protein 1 and myeloid cell leukemia-1 in human oral cancer cell lines. J Oral Pathol Med 44: 785-791, 2015.

58. Hsieh MJ, Chen JC, Yang WE, Chien SY, Chen MK,Lo YS, His YT, Chuang YC, Lin CC and Yang SF: Dehydroandrographolide inhibits oral cancer cell migration and invasion through NF-кB-, AP-1-, and SP-1-modulated matrix metalloproteinase-2 inhibition. Biochem Pharmacol 130: 10-20, 2017.

59. Chen P, Huang HP, Wang Y, Jin J, Long WG, Chen K, Zhao XH, Chen CG and Li J: Curcumin overcome primary gefitinib resistance in non-small-cell lung cancer cells through inducing autophagy-related cell death. J Exp Clin Cancer Res 38: 254, 2019.

60. Lima FT, Seba V, Silva G, Torrezan GS, Polaquini CR, Pinhanelli VC, Baek SJ, Fachin AL, Regasini LO and Marins M: The curcumin analog $\mathrm{CH}-5$ exerts anticancer effects in human osteosarcoma cells via modulation of transcription factors p53/Sp1. Int J Mol Sci 19: 1909, 2018. 